13 - INFORME TÉCNICO

\title{
Telerobotic-assisted laparoscopic operation performed at a remote site: initial experience $^{1}$
}

\author{
Cirurgia laparoscópica robotizada a distância: experiência inicial
}

\author{
Cássio Andreoni ${ }^{2}$, Mardhen Araújo ${ }^{3}$, Nelson Gattás ${ }^{4}$, Valdemar Ortiz ${ }^{5}$, Luiz \\ Francisco Poli de Figueiredo ${ }^{6}$, Miguel Srougi ${ }^{7}$
}

1. Study performed by the Division of Urology at the surgical theaters of the Division of Operative Technique and Experimental Surgery, Department of Surgery, Federal University of São Paulo, UNIFESP/EPM.

2. Assistant Professor, Division of Urology, Department of Surgery, Federal University of São Paulo, UNIFESP/EPM.

3. Postgraduate Fellow, Division of Urology, Department of Surgery, Federal University of São Paulo, UNIFESP/EPM.

4. Assistant Professor, Division of Urology, Department of Surgery, Federal University of São Paulo, UNIFESP/EPM.

5. Associate Professor, Division of Urology, Department of Surgery, Federal University of São Paulo, UNIFESP/EPM.

6. Associate Professor, Division of Operative Technique and Experimental Surgery, Department of Surgery, Federal University of São Paulo, UNIFESP/EPM.

7. Chairman, Division of Urology, Department of Surgery, Federal University of São Paulo, UNIFESP/EPM.

\begin{abstract}
Robotic surgery is an option to laparoscopy that may offer some benefits including the possibility of performing surgery when the surgeon is geographically away from the patient and faster tireless repetitive movements with greater precision. At present, robot-assisted surgery has been done routinely in several institutions around the world, however, to the best of our knowledge, it is the first time such procedure is performed in our academic environment and herein is reported the first telerobotic-assisted laparoscopic cystectomy performed in a domestic pig at our institution using the Zeus? robotic system (Computer Motion, EUA). The procedure was performed using two different operating rooms geographically apart from each other. The assistant was in an operating room that was set with the operating table and the pig as well as with the Zeus? robotic arms. In the other operating room, the surgeon was seated in the control console with a three-dimensional imaging five meters away from the operating table connected with electric cables. The assistant surgeon established the pneumoperitoneum and five trocars were placed in a fan configuration. The surgeon started performing the surgery using three out of the five ports taking control of the laparoscope (voice control) and manual control of laparoscopic instruments connected to the robotic arms using the joysticks. The other two ports were used by the assistant for traction and clips placement that was also necessary for exchanging the many laparoscopic instruments connected to the robot. The laparoscopic total cystectomy was successfully performed in 25 minutes with no complications. The truly benefits as well as the cost-effectiveness of the robotic surgery in our environment is yet to be determined after experience acquisition with telerobotic before start performing
\end{abstract}


such procedures routinely in humans. The present report shows the technical feasibility of telerobotic surgery in a developing country.

Key words: Surgical technique. Laparoscopy. Robotics. Cystectomy.

\section{RESUMO}

A cirurgia totalmente robotizada é uma opção à laparoscopia que pode proporcionar alguns benefícios, entre os quais a realização dos incansáveis movimentos de repetição com maior precisão e rapidez e com o cirurgião localizado em ambiente geograficamente diferente do paciente. Relatamos, em nossa instituição, a primeira cistectomia totalmente robotizada à distância em um porco (raça Landrace) doméstico com o sistema robótico Zeus? (Computer Motion, EUA). A cirurgia foi realizada em duas salas geograficamente separadas, sendo que em uma delas, o porco foi posicionado na mesa cirúrgica bem como os braços do sistema Zeus? fixados de forma segura. Na seqüência, o assistente introduziu os cinco trocateres em forma de leque pela via transperitoneal após obtenção do pneumoperitônio pelo método fechado. Em outra sala, o cirurgião principal comandava os braços do robô através de controles manuais sentado dentro do console de comando do sistema Zeus ?, auxiliado por imagem de vídeo em três dimensões transmitida pelo laparoscópio, que era comandado por sistema de voz, pelo cirurgião. A distância do console de comando e da mesa cirúrgica era de 5 metros e estes estavam conectados por cabos elétricos. A cistectomia total foi realizada em 25 minutos sem intercorrências. $\mathrm{O}$ assistente auxiliou apenas nas manobras de troca de instrumento do sistema Zeus ?, apresentação dos tecidos e introdução do clipador, utilizando apenas dois trocartes. Os reais benefícios do sistema robótico em nosso meio ainda será determinado através da aquisição de maior experiência com o sistema e pelo início da realização deste procedimento em humanos.

Descritores: Robótica. Laparoscopia. Técnica operatória.

\section{Introduction}

The first telerobotic surgery, with the patient and the surgeon geographically apart from each other, was performed in September, 1995, transmitted by optical fibers when a prostate biopsy was carried out (1). This technological development gave an impulse to many other telerobotic procedures, allowing the urologists to accomplish even more complex surgeries, such as spermatic vein ligation, renal biopsy, percutaneous renal access, nephrectomy and pyeloplasty (2). Coming along with such worldwide technological advance, the feasibility of telerobotic surgery at our institution was tested and it is herein reported as an original report from our local academic environment.

\section{Case report}

On June $25^{\text {th }}, 2003$, a domestic pig (Landrace, $23 \mathrm{~kg}$ ) underwent telerobotic-assisted laparoscopic cystectomy using the Zeus? robotic system (Computer Motion, Santa Bárbara, EUA) at the surgical theaters of the Division of Operative Technique and 
Experimental Surgery, Department of Surgery, Federal University of São Paulo. The procedure was carried out using two different operating rooms geographically apart with no direct view from each other. In the main operating room, the pig was placed in the Trendlemburg supine position with the three robotic arms attached to the operating table (Figure 1).

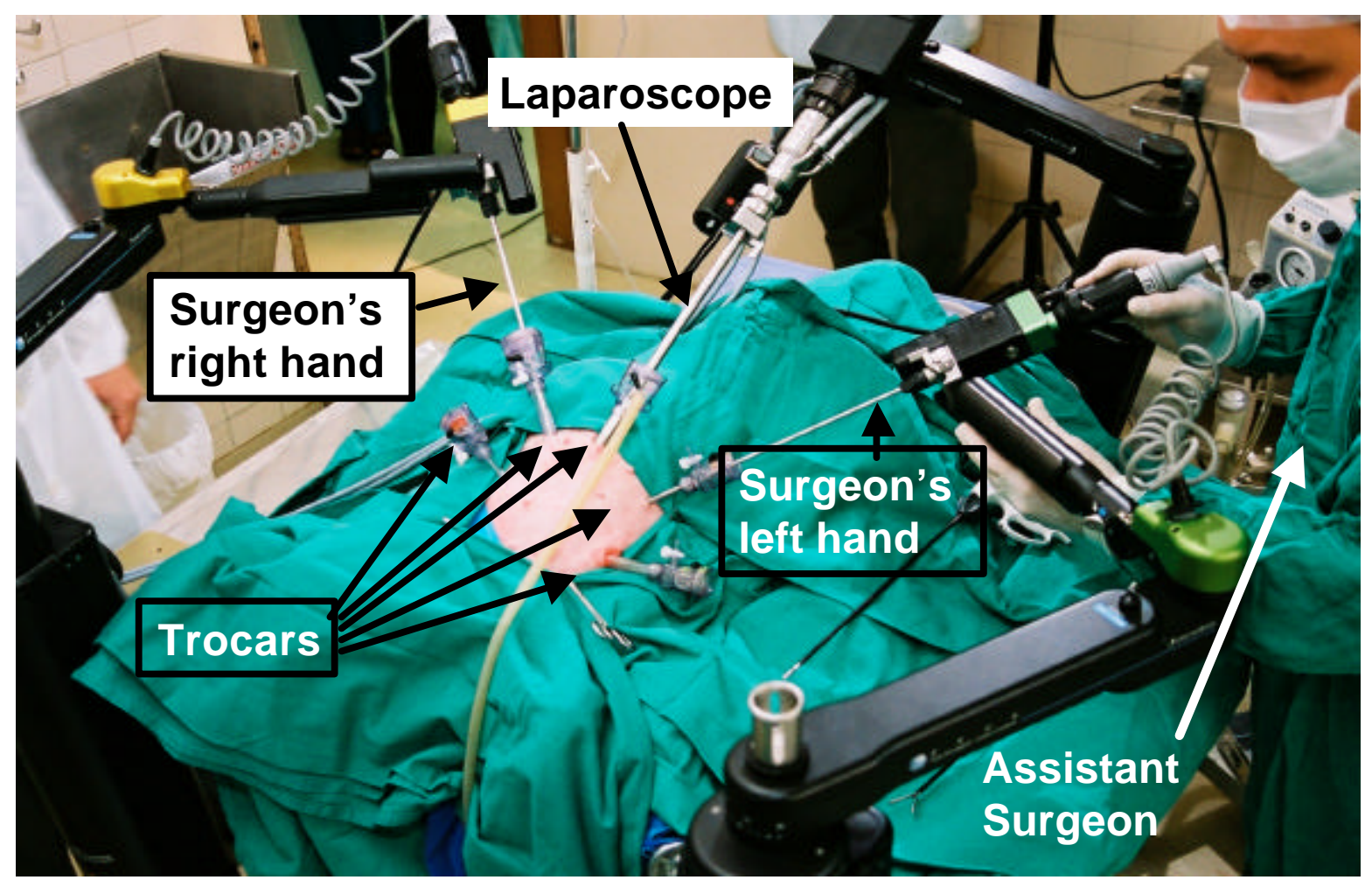

FIGURE 1 - Robot positioning on the operating table and trocar placement for telerobotic-assisted laparoscopic cystectomy.

In the other operating room, the surgeon was seating in the control console of the Zeus? robotic system performing the surgery, taking control of the laparoscope (voice control) and manual control of laparoscopic instruments connected to the robotic arms using the joysticks (Figure 2). 


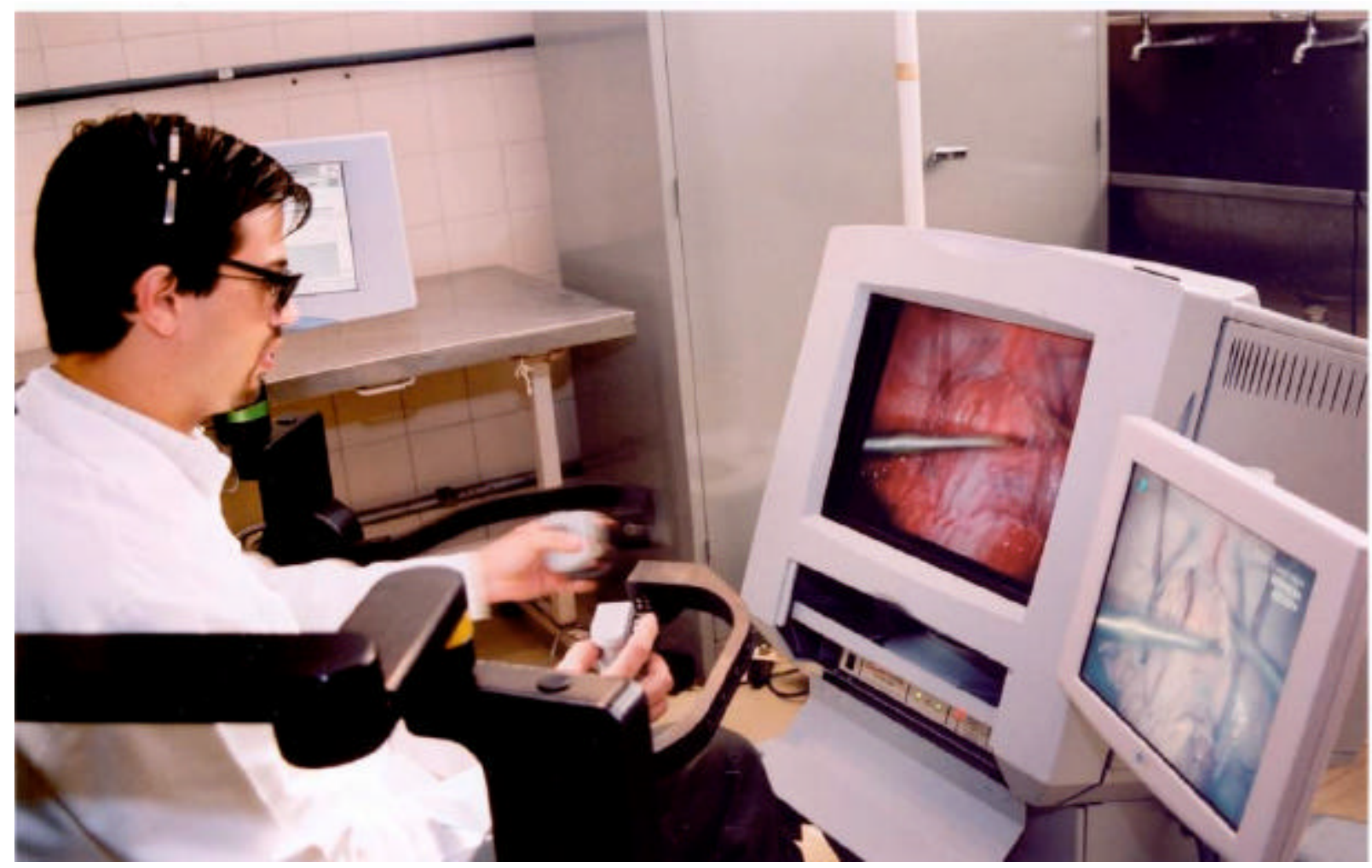

FIGURE 2 - The main surgeon is in the control console of the Zeus?, geographically apart from the main OR, dissecting the bladder under a three-dimensional image.

The assistant surgeon located in the main operating room established the pneumoperitoneum and placed 5 trocars in a fan configuration (Figure 1). The 30 degree laparoscope and the laparoscopic instruments attached to the robotic arms were inserted in the abdominal cavity through trocars already placed by the assistant surgeon, beginning the procedure. The assistant surgeon remained besides the operating table throughout the procedure, exchanging the laparoscopic instruments used by the surgeon, performing tissue traction and clip placement during ligation of the lateral pedicles of the bladder, always following the surgeon's command. The bladder was grasped and dissected out with endoshears by the main surgeon, followed by urethral section and complete bladder removal, thus, completing the procedure successfully within 25 minutes, with no bleeding. No reconstruction was performed and the animal was killed with anesthesia overdose and saturated potassium chloride injection at the end of the surgery.

\section{Discussion}

The first telerobotic-assisted laparoscopic surgery at our institution was performed in accordance with a basic principle: the master-slave system, in which the main surgeon is the master of all actions performed throughout the procedure by the robot that must obey promptly. That is a basic principle used mainly as a mean of safety and it avoids that the robot takes over and eventual mechanical flaws may cause irreversible accidents. Another 
important safety device found in the Zeus? robotic system is the control pedal, which must be activated (stepped) by the surgeon in order to transmit all the surgeon's commands to the robotic arms, and when it is inactive, all the robotic movements stop suddenly, avoiding accidents related to inadvertent actions.

The assistant surgeon mentioned technical difficulties during laparoscopic instruments insertion and operation because of the small room between the robotic arms and the trocars. This reduced working space also turned the assistant instruments out of the way when the robotic arms movements controlled by the surgeon inadvertently hit his instruments, but such deviation did not cause any accidents, but we learned to create a larger room next time.

The main benefit of the robotic system to laparoscopy is the faster tireless repetitive movement with more precision, allowing movements with 6 degrees of freedom against 4 possible degrees with laparoscopy. Moreover, it can be performed when the surgeon is geographically away from the patient. Disadvantages are the loss of tactile feedback, long instrument exchange time throughout the procedure and the high initial financial investment ${ }^{3}$.

The telerobotic-assisted surgery is part of the present. The truly benefits and costeffectiveness of the assimilation in the operating room routine of such technology in our environment is yet to be determined with the beginning and larger experience in humans. Nevertheless, the initial experience with telerobotic-assisted surgery herein reported show the feasibility of such procedure in a developing country.

\section{References}

1. Rovetta A, Bejczy AK, Sala R. Telerobotic surgery: applications on human patients and training with virtual reality. Stud Health Technol Inform 1997;39:508-17.

2. Bove $\mathrm{P}$, Stoianovici $\mathrm{D}$, Micali $\mathrm{S}$ et al. Is telesurgery a new reality? Our experience with laparoscopic and percutaneous procedures. J Endourol 2003;17:137-42.

3. Shah J, Mackay S, Vale J et al. Urorobotics: robots in urology. BJU International, 2001;88:313-20.

Correspondence:

Dr Cássio Andreoni

Rua Jesuíno Arruda, 60/201

04532-080 São Paulo - SP

c.andreoni@attglobal.net

Data do recebimento: $12 / 02 / 2004$

Data da revisão: 11/03/2004

Data da aprovação: 02/04/2004

Conflict of interest: none

Financial source: none 
How to cite this article:

Andreoni C, Araújo M, Gattás N, Ortiz V, Poli de Figueiredo LF, Srougi M. Teleroboticassisted laparoscopic operation performed at a remote site: initial experience. Acta Cir Bras [serial online] 2004 May-Jun;19(3). Available from URL: http://www.scielo.br/acb. [also in CD-ROM]. 